\title{
KOMUNIKASI INTERPERSONAL HAKIM MEDIATOR DALAM MENYELESAIKAN PERKARA PERCERAIAN DI MAHKAMAH SYARI'AH KOTA LHOKSEUMAWE
}

\author{
Oleh \\ Anna Syafitri Barus ${ }^{1}$, Juwita Manda Pratiwi \& Awaludin \\ Arifin ${ }^{2}$ \\ Email: annasyafitribaru@gmail.com \\ 1 Dosen Program Studi Ilmu Komunkasi Universitas Medan Area. \\ 2. Dosen Program Studi Ilmu Komunikasi Univesitas Malikussaleh
}

\begin{abstract}
Abstrak
Upaya memediasi kasus perceraian merupakan upaya kompleks yang diambil oleh hakim mediator. Proses mediasi menitik beratkan pada proses komunikasi dua arah dan melibatkan kedua belah pihak. Proses mediasi dilakukan secara terpisah atau bisa secara langsung kepada kedua belah pihak. Proses seperti ini disebut dengan proses "kaukus". Strategi lainnya yaitu dengan meminta wali atau orang tua untuk ikut menasehati. Hakim mediator juga mengajak kedua belah pihak agar berfikir dengan matang perceraian yang diinginkan, mengingat anak-anak butuh keberadaan mereka berdua. Hasil penelitian ini juga memperlihatkan bahwa dari 100 kasus yang dimediasi oleh hakim mediator, hanya satu diantaranya yang berhasil rujuk (tidak jadi cerai). Penelitian menggunakan pendekatan kualitatif, dimana penelitian ini mengedepankan pengamatan dan hasil wawancara untuk mendapatkan informasi dan data yang akurat di lapangan.
\end{abstract}

Kata kunci: Komunikasi interpersonal, hakim mediator, dan mahkamah syariah.

\section{Pendahuluan}

Komunikasi interpersonal adalah komunikasi antara orangorang secara tatap muka, yang memungkinkan setiap pesertanya menangkap reaksi orang lain secara langsung, baik secara verbal maupun nonverbal. Seperti komunikasi padaumumnya, komunikasi interpersonal selalu mencakup dua unsur pokokyaitu isi pesan dan bagaimana isi pesan dikatakan atau dilakukan secaraverbal atau nonverbal (Mulyana, 2008:81). 
Komunikasi interpesonal juga digunakan oleh hakim. Dimana hakim ialah pejabat peradilan negara yang diberi wewenang oleh undang-undang untuk mengadili (Pasal 1 butir 8 KUHAP). Tugas yang dijalankan oleh seorang hakim untukmengadili serangkaian tindakan hakim untuk menerima, memeriksa dan memutus perkara pidana berdasarkan asas bebas, jujur dan tidak memihak di sidang pengadilan dalam hal dan menurut cara yang diatur dalam undang-undang ini (Pasal 1 Ayat (9) KUHAP).

Dalam melaksanakan tugas seorang hakim, komunikasi interpersonal sangat berperan dalam menjalankan tugasnya dan mediasi salah satu tugas yang menggunakan komunikasi interpersonal. Mediasi adalah cara menyelesaikan sebuah perkara melalui proses perundingan untuk memperoleh kesepakatan antara pihak-pihak dengan bantuan sang mediator dan mediator hakim juga termaksud mediator dalam proses mediasi.

Pada suatu perkara hakim juga berperan sebagai mediator bagi pihak-pihak yang terlibat dalam sebuah mediasi. Banyak perkara yang biasa dijalankan oleh hakim untuk menjalankan mediasi, salah satunya ialah perkara perceraian. Perceraian, sebuah perkara yang diajukan oleh salah satu dari pihak suami atau istri untuk mengakhiri hubungan pernikahan secara hukum. Suami istri sendiri merupakan sepasang makhluk hidup yang menjalankan hubungan secara sah yang bertujuan untuk hidup bersama.

Namun, banyaknya persoalan yang ada dikehidupan, membuat banyak pasangan suami istri berhenti memutuskan hubungan dan mengajukan perkara perceraian di pengadilan yang ada, beberapa alasan perceraian yang terjadi yaitu, tidak adanya tanggung jawab, masalah ekonomi, cemburu diluar kata wajar, krisis akhlak yang dimiliki, kekejaman mental atau kekerasan dalam rumah tangga, adanya pihak ketiga, hilangnya keharmonisan dan banyak hal lainnya hingga memicu hubungan suami istri itu kandas ditengah jalan.

Perceraian juga termaksud salah satu dari banyaknya perkara yang terjadi di mahkamah Syar'iyah. Mahkamah Syar'iyah sendiriperadilan yang menangani segala perkara yang ada di masyarakat serta sebagai tempat hakim melakukan tugasnya. Pada kasus perceraian yang ada, komunikasi interpersonal berperan penting dalam sebuah mediasi dalam menjalankan tugas hakim sebagai mediator pada saat mediasi. Dari komunikasi interpersonal 
yang digunakan hakim kepada pihak yang tersangkut dapat menemukan solusi dari sebuah perkara hingga dalam kasus perceraian suami istri dengan adanya mediasi dapat berhenti memutuskan perceraian atau rujuk.

Peneliti tertarik untuk mengangkat alasan sederhana ingin melihat metode komunikasi interpersonal yang dilakukan seorang hakim sebagai mediator dalam menangani kasus perceraian, dengan alasan perkara mengenai perceraian suami istri yang sangat disayangkan harus berakhir di pengadilan, dimana kasus perceraian salah satu perkara yang lumayan banyak terjadi. oleh karena itu, peneliti ingin melihat kinerja yang dijalankan oleh seorang hakim dengan menggunakan komunikasi interpersonal dalam mediasi saat perceraian.

Perceraian adalah salah satu hal yang sangat disayangkan jika terjadi, dengan itu pentingnya sebuah mediasi demi mengharapkan hal baik sehingga sebuah perceraian dapat dicegah. Hakim disini berperan sebagai penengah yang memberi mediasi biasa dilakukan antara per orang suami istri atau keduanya secara langsung. Disinilah berperan sebuah komunikasi interpersonal agar sebuah mediasi berjalan dengan lancar dan mengharapkan umpan balik yang positif.

Peneliti menjadi tertarik untuk melakukan penelitian terhadap salah satu Mahkamah Syar'iyah di Kota Lhokseumawe, dimana sebagai tempat peradilan yang sangat berperan dalam penanganan kasus perceraian suami istri yang ada di Kota Lhokseumawe. Dengan itu penelitiingin melihat komunikasi interpersonal hakim dalam memberikan mediasi kepada pasangan suami istri dan ingin melihat seberapa berperan komunikasi interpersonal hakim dalam menangani mediasi perceraian pada pasangan suami istri.

".

Peneliti telah melakukan observasi awal dengan bertanya sekilas dengan salah satu hakim langsung mengenai mediasi dipengadilan yang memperkirakan pada setahun masyarakat aceh kurang lebih mengajukan sejumlah 500 kasus perceraian, dan ini sangat memprihatinkan dengan banyaknya jumlah angka perceraian di Kota Lhokseumawe hingga dapat menjadi sebuah acuan bahan lanjutan pada skripsi ini

\section{Landasan Teori}




\section{Komunikasi Interpersonal}

Joseph A. Devito (dalam Uchjana, 2003: 60) mendefinisikan komunikasi interpersonal sebagai 'the process of sending and receiving messages between two persons, or among a small group of persons, with some effect and some immediate feedback' (proses pengiriman dan penerimaan pesan-pesan antara dua orang, atau diantara sekolompok kecil orang-orang dengan beberapa efek dan beberapa umpan balik seketika). Ketika komunikator menyampaikan pesan, maka pada saat itu juga ia dapat mengetahui tanggapan komunikan terhadap pesan yang disampaikan. Apabila tanggapan komunikan positif, maka komunikator akan mempertahankan gaya komunikasinya. Namun, jika tanggapan negatif maka komunikator harus mengubah gaya komunikasinya sampai komunikasinya berhasil.

Dedy Mulyana (2008:81) komunikasi interpersonal atau komunikasi antarpribadi adalah komunikasi antara orang-orang secara tatap muka, yang memungkinkan setiap pesertanya menangkap reaksi orang lain secara langsung, baik secara verbal maupun nonverbal.

Komunikasi interpersonal merupakan komunikasi yang pesannyadikemas dalam bentuk verbal atau nonverbal.Seperti komunikasi padaumumnya, komunikasi interpersonal selalu mencakup dua unsur pokokyaitu isi pesan dan bagaimana isi pesan dikatakan atau dilakukan secaraverbal atau nonverbal. Dua unsur tersebut sebaiknya diperhatikan dandilakukan berdasarkan pertimbangan situasi, kondisi, dan keadaanpenerima pesan.

Komunikasi interpersonal merupakan kegiatan aktif bukan pasif.Komunikasi interpersonal bukan hanya komunikasi dari pengirim padapenerima pesan, begitupula sebaliknya, melainkan komunikasi timbalbalik antara pengirim dan penerima pesan. Komunikasi interpersonalbukan sekedar serangkaian rangsangantanggapan, stimulus-respon, akan tetapi serangkaian proses saling menerima, penyeraan dan penyampaiantanggapan yang telah diolah oleh masing-masing pihak. Hubunganinterpersonal perlu ditumbuhkan dan ditingkatkan dengan memperbaiki hubungan dan kerjasama antara berbagai pihak.

Komunikasi interpersonal dinyatakan efektif bila pertemuankomunikasi merupakan hal yang menyenangkan bagi komunikan.Menurut sifatnya, komunikasi interpersonal dapat dibedakan atas dua macam, yaitu komunikasi diadik (dyadic 
communication) dan komunikasi kelompok kecil (small group communication).

a. Komunikasi diadik (dyadic communication) Komunikasi diadik adalah komunikasi interpersonal yang berlangsung secara tatap muka misalnya berdialog atau wawancara langsung.

b. Komunikasi kelompok kecil (small group communication) Komunikasi kelompok kecil adalah komunikasi interpersonal yang pelaku komunikasinya terdiri dari tiga orang atau lebih secara tatap muka, dimana anggotaanggota saling berinteraksi satu sama lainnya.

Jika dibandingkan antara keduanya maka komunikasi diadik lebih efektif, karena komunikator memusatkan perhatiannya kepada seorang komunikan sehingga dapat menguasai frame of reference komunikan secara penuh.

\section{Metode Penelitian}

Pendekatan yang digunakan dalam penelitian ini adalah pendekatan kualitatifyang bersifat deskriptif.Moleong (2006:190) penelitian kualitatif merupakan suatu pendekatan dalam melakukan penelitian yang berorientasikan pada gejala atau fenomena yang bersifat alami. Mengingat orientasinya demikian maka sifatnya mendasar dan naturalistik atau bersifat kealamiahan serta tidak bisa dilakukan di laboratorium melainkan dilapangan.

Data yang diperoleh bersifat deskriptif yang berupa katakata lisan atau ungkapan dan gambaran dimana data tersebut diperoleh dari hasil wawancara dan pengamatan. Pendekatan ini menyebutkan bahwa tindakan manusia menjadi suatu hubungan sosial bila manusia memberikan arti atau makna tertentu terhadap tindakannya. Sehingga data yang berada dilapangan mampuu mengungkapkan interpretasi subyek akan perilakunya. (Moleong,2006:6)

Penentuan informan, peneliti menggunakan teknik purposive sampling.Teknik purposive sampling adalah teknik penentuan sampel untuk tujuan tertentu saja. Purposive sampling juga bisa berarti sampling yang menentukan target kelompok tertentu. Informan dalam penelitian ini terdiri dari 2 Hakim, 2 Suami dan 2 Istri kasus perceraian berjumlah 6 orang

\section{Hasil Penelitian dan Pembahasan}




\section{Sejarah Mahkamah Syar'iyah Lhokseumawe}

Mahkamah Syar'iyah terletak di Jl. Banda Aceh-Medan, Desa Alue Awe, Kec. Muara Dua, Kota Lhokseumawe dan telah dibentuk sejak tahun 1961. Pengadilan Agama tingkat pertama dan tingkat banding di Propinsi Daerah Istimewa Aceh semula dibentuk berdasarkan peraturan Pemerintah No.29 tahun 1957 (Lembaran Negara tahun 1957 No.73). Akan tetapi Peraturan Pemerintah tersebut kemudian dicabut kembali dan ditetapkan Peraturan Pemerintah No. 45 tahun 1957 (Lembaran Negara tahun 1957 No. 99) untuk keseragaman dasar Hukum dan kewenangan Pengadilan Agama atau Mahkamah Syar'iyah diluar Jawa dan Madura.

Berdasarkan Penetapan Menteri Agama No. 58 tahun 1957 sebagai realisasi dari pasal 12 Peraturan Pemerintah No. 45 tahun 1957, maka sejak tanggal 1 Desember 1957 Daerah Istimewa Aceh terdapat sebuah Pengadilan Agama tingkat banding dengan nama Pengadilan Agama/Mahkamah Syar'iyah Propinsi dan 16 buah Pengadilan Agama tingkat pertama. Selanjutnya berdasarkan Keputusan Menteri Agama No. 62 tahun 1961, sejak tanggal 25 Juli 1961 dibentuk lagi sebuah cabang Pengadilan Agama yang berkedudukan di Lhokseumawe dengan nama Mahkamah Syar'iyah Lhokseumawe. Kemudian Mahkamah Syar'iyah Lhokseumawe berubah namanya Menjadi Pengadilan Agama Lhokseumawe dengan berlakunya Undang-Undang No. 7 tahun 1989 tentang Pengadilan Agama. Dengan berlakunya UndangUndang tentang Pengadilan Agama tersebut, maka resmi dan kuatlah keberadaan Badan Peradilan Agama di Daerah Istimewa Aceh (Vide pasal 106 ayat (1) Undang-Undang No. 7 tahun 1989).

Pada tanggal 3 Maret 2003 berubah lagi nama Pengadilan Agama Lhokseumawe menjadi Mahkamah Syar'iyah Lhokseumawe. Kemudian dengan lahirnya Keputusan Presiden RI Nomor: 11 Tahun 2003 tentang Mahkamah Syar'iyah dan Mahkamah Provinsi di Provinsi Nanggro Aceh Darussalam.Sesuai dengan Keputusan Ketua Mahkamah Agung RI. tanggal 06 Oktober 2004, Nomor : 070/K/H/2004, tentang pengalihan sebagian tugas Pengadilan Negeri ke Mahkamah Syar'iyah, dan Peresmian Operasional Kewenangan Mahkamah Syar'iyah tersebut oleh Ketua Mahkamah Agung Republik Indonesia tanggal 11 Oktober 2004 di Banda Aceh, maka tugas Mahkamah Syar'iyah melingkupi perkara Perdata dan sebahagian perkara Pidana (Jinayah). 
Penandatanganan persetujuan damai antara Pemerintah Republik Indonesia dengan GAM di Helsinki tanggal 15 Agustus 2005 telah melahirkan UU No. 11 tahun 2006 tentang Pemerintah Aceh, yang ikut memperkuat kedudukan Mahkamah Syar'iyah dengan memberi tempat khusus sebagai salah satu alat kelengkapan Pemerinah Aceh yang berfungsi sebagai lembaga yudikatif, dan berdampingan dengan kekuasaan eksekutif dan legislatif daerah.Mahkamah Syar'iyah merupakan Peradilan Syari'at Islam di Provinsi Nanggroe Aceh Darussalam, sesuai dengan pasal 128 s/d 138 UUPA No. 11 Tahun 2006, jo. Qanun Provinsi Nanggroe Aceh Darussalam No. 10 Tahun 2002 jo. KEPPRES No. 11 Tahun 2003.

Tabel .1

Data Perkara Perceraian Tahun 2016

\begin{tabular}{|l|c|}
\hline $\begin{array}{c}\text { Perkara Perceraian Tahun 2016 } \\
\text { Mahkamah Syar'iyah } \\
\text { Lhokseumawe }\end{array}$ & Jumlah Perkara \\
\hline Januari & 49 \\
\hline Februari & 25 \\
\hline Maret & 50 \\
\hline April & 60 \\
\hline Mei & 41 \\
\hline Juni & 35 \\
\hline Juli & 24 \\
\hline Agustus & 27 \\
\hline September & 31 \\
\hline Oktober & 42 \\
\hline November & 34 \\
\hline Desember & 40 \\
\hline Total Jumlah Perkara Perceraian $=458$ \\
\hline \multicolumn{2}{|l|}{ Sumber| } \\
\hline
\end{tabular}

Sumber : Dokumen Mahkamah Syar'iyah Kota Lhokseumawe

\section{Tabel .2}

Data Perkara Perceraian Tahun 2017

\begin{tabular}{|l|c|}
\hline $\begin{array}{c}\text { Perkara Perceraian Tahun 2017 } \\
\text { Mahkamah Syar'iyah } \\
\text { Lhokseumawe }\end{array}$ & Jumlah Perkara \\
\hline Januari & 16 \\
\hline
\end{tabular}




\begin{tabular}{|l|c|}
\hline Februari & 27 \\
\hline Maret & 36 \\
\hline April & 32 \\
\hline Mei & 26 \\
\hline Juni & 23 \\
\hline Juli & 26 \\
\hline Agustus & 36 \\
\hline September & 42 \\
\hline Oktober & 85 \\
\hline November & 36 \\
\hline Desember & 36 \\
\hline Total Jumlah Perkara Perceraian $=421$ \\
\hline \multicolumn{2}{|c|}{ Sumber : dokumen Mahkamah Syar'iyah Kota Lhokseumawe }
\end{tabular}

\section{Strategi Komunikasi Interpersonal Hakim Mediator pada} Kasus Perceraian di Mahkamah Syar'iyah Kota Lhokseumawe

Komunikasi interpersonal adalah komunikasi antara dua orang atau lebih secara tatap muka, yang memungkinkan setiap pesertanya menangkap reaksi orang lain secara langsung, baik secara verbal maupun nonverbal. Komunikasi interpersonal merupakan kegiatan aktif bukan pasif. Komunikasi interpersonal bukan sekedar stimulus-respon, akan tetapi serangkaian proses saling menerima, pesan. Hubungan interpersonal perlu ditumbuhkan dan ditingkatkan dengan memperbaiki hubungan dan kerjasama antara berbagai pihak.

Dalam penelitian ini, komunikasi interpersonal dilakukan oleh seorang hakim dan orang yang memiliki masalah pada kasus yang paling banyak masuk laporannya ke Mahkamah Syar'iyah yaitu kasus gugatan perceraian.Komunikasi ini terjadi khususnya saat melakukan mediasi antara orang yang memiliki kasus tersebut.Mediasi sendiri adalah proses atau usaha seorang hakim untuk membahas perkara dengan mengharapkan adanya perdamaian.

Oleh karena itu, hakim adalah seseorang yang berwenang dalam hal mediasi. Maka itu, pada saat-saat tertentu, tugas hakim akan beralih otomatis menjadi mediator dan hakim harus melakukan mediasi terhadap pasangan suami istri yang akan bercerai. Berdasarkan hasil wawancara dengan salah seorang Hakim Mahkamah Syar'iyah Lhokseumawe sekaligus mediator 
dalam hal kasus perceraian tersebut,DRS. Nailul Syukri SH.,MH (51) menyatakan:

"Saya berperan sebagai mediator dalam kasus mediasi perceraian sudah beberapa kali, tergantung kesepakatan yang ditunjuk oleh majelis hakim atau berasal dari kedua belah pihak yang megharuskan saya menjadi mediator pada saat mediasi, jika tidak dapat di alihkan oleh mediator majelis hakim atau mediator luar yang namanya telah terdaftar dipengadilan"(Wawancara, 5 Januari 2018).

Selain itu, Robinhot Kaloko, SH.MH (57) yang juga merupakan Hakim Mahkamah Syar'iyah Lhokseumawe dan sekaligus mediator dalam hal kasus perceraian menyatakan bahwa :

"Ya, saya bahkan sangat sering menjadi mediator dalam sebuah mediasi yang saya pimpin sendiri sebagai hakim"(Wawancara, 5 Januari 2018).

Pernyataan senada juga disampaikan oleh Vera (33), penggugat perceraian atau istri dari Al, di Mahkamah Syar'iyah Lhokseumawe:

"Iya, waktu saya melakukan mediasi, pada saat itu yang menjadi mediator adalah seorang hakim juga yang menangani kasus perceraian saya" (Wawancara, 1 Januari 2018).

Mediasi dapat dilakukan oleh seorang hakim sesuai arahan majelis hakim atau kesepatakan kedua belah pihak penggugat perceraian.Jika ingin menjadi seorang hakim sebagai mediator dan seorang mediator lainnya, dari seorang mediator pengadilan maupun mediator luar yang namanya telah terdaftar di pengadilan Mahkamah Syar'iyah Kota Lhokseumawe.

Dalam hal ini, seorang hakim harus memahami dengan baik mengenai mediasi hingga dapat menyampaikan mediasi dengan baik. Seperti pernyataan, DRS. Nailul Syukri SH.,MH (51)Hakim Mahkamah Syar'iyah Lhokseumawe :

"Saya, dapat menjadi seorang mediator juga tidak bisa sembarangan, saya harus memiliki ilmu komunikasi dengan baik, bagaimana saya

94

Jurnal Jurnalisme Volume 7 No. 1 Edisi April 2018 
menyampaikan komunikasi dari pihak satu ke pihak lainnya dalam menyelesaikan perkara dan juga memahami ilmu yang mendalami tentang mediasi salah satunya yaitu, perma no 1 tahun 2016 tentang proses prosedur penyelesaian mediasi di pengadilan " (Wawancara, 5 Januari 2018).

Pernyataan senada disampaikan oleh, Robinhot Kaloko, SH., MH(57)Hakim Mahkamah Syar'iyah Lhokseumawe :

"Ya, jelas saya harus memamahi dengan baik, dan memiliki komunikasi yang baik untuk membicarakan proses yang ada di mediasi karena saya juga pernah berjabat sebagai wakil ketua hakim disini, yang seharusnya memiliki pengetahuan dan tanggung jawab yang lebih besar dalam menjalankan mediasi ataupun tugas apapun dan ini juga berlaku pada semua hakim atau mediator"(Wawancara, 5 Januari 2018).

Seorang hakim yang dapat ditunjuk sebagai seorang mediator dalam kasus perceraian adalah yang memiliki ilmu komunikasi yang baik dalam menyampaikan perkara dari satu pihak ke pihak yang lain, hingga menghasilkan keputusan pada saat di persidangan.

Kemampuan berinteraksi dengan komunikasi interpersonal disini juga harus dimiliki oleh hakim sebagai mediator karena membutuhkan komunikasi interpersonal dengan mendalam, sehingga hakim dapat berperan sesuai tugasnya.Sebab, sebelum proses mediasi, ada beberapa proses yang harus dilakukan terlebih dahulu, baik itu antara hakim dan suami atau istri.

Beberapa proses sebelum mediasi ini disampaikanDRS.

Nailul Syukri SH.,MH (51)Hakim Mahkamah Syar'iyah Lhokseumawe :

"Awal proses adanya perceraian yaitu membuat gugatan kepada pengadilan mahkamah syar'iyah, serta pengadilan meminta bukti-bukti yang kuat dari kedua belah pihak dan jika bukti sudah kuat mendukung permohonanya atau gugatan di 
kabulkan oleh pihak Mahkamah Syar'iyah " (Wawancara, 5 Januari 2018)

Dari pernyataan tersebut, proses perceraian memang bukan masalah yang bisa diproses dengan mudah di Pengadilan Mahkamah Syar'iyah.Hanya kasus yang dinyatakan bermasalah dan berat yang dapat diproses di pengadilan.Hal ini juga dinyatakan oleh Robinhot Kaloko, SH.,MH(57)Hakim Mahkamah Syar'iyah Lhokseumawe :

"Iya seperti dipengadilan pada umumnya, mengajukan jika perkaranya memang pantas untuk di bawa ke pengadilan akan diproses selanjutnya"(Wawancara, 5 Januari 2018).

Hal tersebut diperkuat oleh pernyataan yang disampaikan Vera (33) pengugat perceraian atau istri dari Al di Mahkamah Syar'iyah Lhokseumawe:

"Saya yang mengajukan perceraian, menyerahkan berkas-berkas kepada Mahkamah Syar'iyah dengan bukti yang ada, salah satunya menunjukan berkas visum hasil kekerasan rumah tangga yang saya alami dan adanya orang ketiga" (Wawancara, 1 Januari 2018)

Pernyataan senada juga disampaikan, Lia (28), penggugat perceraian atau istri Muzam di Mahkamah Syar'iyah Lhokseumawe:

"Saya menerima panggilan yang telah diajukan oleh suami saya" (Wawancara,5 Januari 2018)

Pada pernyataan tersebut, dalam menjalankan sebuah proses mediasi yang dilakukan seorang hakim, sebelumnya mengharuskan gugatan perceraian di lengkapi bukti sehingga dapat menjalankan ke proses di pengadilan hingga sampai ke proses mediasi. Proses mediasi dilakukan oleh hakim, baik antar pihak atau kepada salah satu pihak. 
Dalam proses mediasi tersebut, tentu hakim harus memiliki kemampuan berinteraksi dengan baik kepada yang memiliki masalah agar mediasi berhasil. Hal ini juga diutarakan olehDRS. Nailul Syukri, SH.,MH (51)Hakim Mahkamah Syar'iyah Lhokseumawe :

"Selain saya harus memiliki komunikasi yang baik, ini berfungsi supaya proses mediasi yang saya jalankan tersampaikan dengan baik, biasa saya melakukan komunikasi saat mediasi antar pihak secara terpisah, karena biar lebih mendetail melihat, dimana permasalahan yang ada setelah itu baru saya lanjutkan langsung kedua belah pihak" (Wawancara, 5 Januari 2018)

Berdasarkan hal tersebut, hakim memiliki strategi tersendiri dalam melaksanakan proses mediasi. Salah satu strategi awal termasuk dari pernyataan Vera (33) Penggugat perceraian atau istri dari Al di Mahkamah Syar'iyah Lhokseumawe:

"Saat berada di proses mediasi, mediator langsung berbicara dengan saya hanya berdua dengan menanyakan serta membahas alasan utama saya menggugat suami saya dan saat itu juga saya didampingi ibu saya" (Wawancara, 1 Januari 2018).

Pada tahap awal tersebut, hakim memakai sistem kaukus terlebih dahulu. Kaukus adalah proses awal di mana hakim berkomunikasi empat mata dengan penggungat atau penerima gugatan perceraian. Hal ini juga dinyatakan oleh $\mathrm{Al}$ (37) penerima gugatan perceraian atau suami Vera (33) di Mahkamah Syar'iyah Kota Lhokseumawe:

"iya, mediator berbicara hanya berdua dengan saya pada saat mediasi" (wawancara, 2 Januari 2018).

Berdasarkan strategi tersebut, hakim, pihak penggugat dan tergugat di kasus perceraian menyatakan, jika hakim melakukan komunikasi interpersonal secara mendalam kepada masing-masing 
pihak, kemungkinan merekan akan lebih mudah mendapatkan titik temu untuk menentukan hasil persidangan. Karena dalam pembicaraan yang hanya terjalin antara hakim dan suami atau istri saja maka akan lebih leluasa untuk mengajak mereka untuk tidak bercerai.

Hakim dapat menerapkan strategi kaukus dalam mediasi interpersonal tersebut. Salah satu contohnya adalah dengan menjadikan anak sebagai salah jembatan penyambung suami istri yang ingin bercerai tersebut. Hal ini termasuk salah satu bagian dari strategi yang dilakukan oleh hakim mediator.

Awal melakukan mediasi, hakim melakukan perkenalan diri dan memeriksa data pihak yang bersangkutan dan melakukan mediasi baik dengan kedua pihak perceraian maupun masing-masing pihak sebagai salah satu strategi komunikasi yang mendalam yang dilakukan seorang hakim sebagai mediator.

Hal tersebut juga dilakukan agar proses mediasi berjalan dengan nyaman dari berbagai pihak. Agar dalam menyampaikan strategi komunikasi dalam mediasi berjalan lancar sebab telah terciptanya kenyamanan. DRS. Nailul Syukri, SH., MH (51)Hakim Mahkamah Syar'iyah Lhokseumawe menyatakan :

"Iya, setelah kaukus salah satu strategi kami, kami juga dapat menghadapkan kedua belah pihak kemudian mediator dapat meminta masingmasing pihak untuk membuat drafkesepakatan atau hal hal yang di inginkan agar dapat disepakati, atau mediator juga bisa membuat draft mediasi langsung dengan mendengar hasil mediasi dari masing-masing pihak yang kedua belah pihak menyepakati apa yang saya buat sebagai mediator mediasi mereka bila kedua belah pihak dapat menyepakati draft tersebut "(Wawancara, 5 Januari 2018)

Setelah menjalankan strategi awal, jika prosesnya masih belum menemukan titik cerah, maka hakim menjalankan strategi berikutnya.Strategi selanjutnya adalah memanggil kedua belah pihak yang mengajukan gugatan untuk di mediasi hakim secara langsung dalam satu pertemuan.Pernyataan tersebut disampaikan 
oleh, Robinhot Kaloko, SH.,MH (57) Hakim Mahkamah Syar'iyah Lhokseumawe :

"Iya, kami melakukan pertemuan juga dikedua belah pihak sebagai salah satu dari strategi mediasi" (Wawancara, 5 Januari 2018).

Pada saat mediasi, hasilnya dibuat menjadi sebuah draft.Hal tersebut disampaikan Al (37)penerima gugatan perceraian atau suami Vera (33) di Mahkamah Syar'iyahLhokseumawe:

"Iya, saat proses perceraian saya, mediator langsung yang membuat draft dari hasil mediasi kami" (Wawancara, 2 Januari 2018)

Draft tersebut dibuat untuk kemudian disepakati bersama oleh penggungat maupun tergugat kasus perceraian. Halini disampaikan olehVera (33)penggugat perceraian atau istri dari $\mathrm{Al}$ di Mahkamah Syar'iyah Lhokseumawe:

"Iya, setelah mediasi, mediator sendiri yang membuat draft perceraian kami dengan melakukan kesepakatan kepada kami" (Wawancara, 1 Januari 2018)

Pernyataan di atas menjelaskan, jika sekalipun mediasi dilakukan oleh seorang mediator, mediator tetap dapat membuat para pihak draft perceraian atau langsung membuat draft perceraian, namun tetap dengan kesepatakan yang ada dari kedua belah pihak. Namun, dalam hal tersebut hakim sebagai mediator tetap harus memiliki sikap netral hingga mediasi menghasilkan keputusan yang tepat dari kedua belah pihak.

Walau bagaimanapun, hakim tetap tidak dibolehkan untuk berpihak kepada yang memiliki kasus tersebut.Berikut pernyataan DRS. Nailul Syukri SH.,MH (51) Hakim Mahkamah Syar'iyah Lhokseumawe :

"Iya, seorang mediator atau khusunya hakim dia akan menjadi netral, harus berpegang teguh dengan pedoman perilaku hakimdan kode etik dan hal ini juga berlaku kepada mediator, karena kami terikat dengan pph serta kode etik hingga 
mewajibkan bersikap netral agar kedua belah pihak tidak dirugikan dengan apapun keputusan selajutnya "(Wawancara, 5 Januari 2018)

Hal tersebut harus dipegang teguh oleh hakim, karena pada dasarnya hakim memang harus memiliki sifat adil.Sebab hal tersebut merupakan salah satu kode etik profesi.Hal ini diperkuat oleh Robinhot Kaloko, SH., MH(57)Hakim Mahkamah Syar'iyah Lhokseumawe :

"Kami hakim tetap harus adil meskipun berada posisi sebagai seorang mediator dengan melihat bagaimana permasalahan dan sudah seharusnya bersikap adil karena itu juga bagian dari kode etik bagi hakim maupun mediator" (Wawancara, 5 Januari 2018).

Pernyataan diatas menjelaskanbahwa, seorang hakim memang sejak awal sudah harusbersikap netral.Karena akan memudahkan hakimpulakala berperan sebagai mediator dalam mediasi. Karena dalam tiap-tiap kasus, terkhusus kasus perceraian, pasti memiliki kesulitan dalam proses penyelesaiannya.

Pada kasus perceraian sendiri, banyak faktor atau penyebab yang terjadi hingga para penggugat dapat memutuskan untuk bercerai.Berikut pernyataanDRS. Nailul Syukri SH,MH (51)Hakim Mahkamah Syar'iyah Lhokseumawe :

"Banyak penyebab, pasangan suami istri memutuskan untuk bercerai, salah satunya tidak memiliki keturunan, tidak harmonis atau rukun dalam berumah tangga, pasangan dalam keadaan sakit baik secara mental dan fisik, adanya pihak ketiga, kekerasan rumah tangga dan banyak lagi alasan lainnya"(Wawancara, 5 Januari 2018)

Hal tersebut jugadisampaikan olehVera (33) penggugat perceraian atau istri Al di Mahkamah Syar'iyah Lhokseumawe:

"Iya, penyebab perceraian sehingga saya memutuskan menggugat suami saya adalah adanya kekerasan rumah tangga, dia menghasilkan uang dengan menjual sabu dan 
adanya orang ketiga yang meenurut saya sudah tidak dapat lagi saya toleransi" (Wawancara, 1 Januari 2018)

Berdasarkan kasus tersebut, terkadang memang ada hal yang tidak dapat lagi ditolerir dalam hubungan rumah tangga.Hal ini juga tergantung dari pribadi individu bagaimana dia menyikapi masalah tersebut.Ini mungkin terjadi sebab faktor internal suami istri. Hal ini dinyatakan oleh Robinhot Kaloko, SH., MH (57)Hakim Mahkamah Syar'iyah Lhokseumawe :

"Iyah, banyak penyebab terjadinya kenapa pihak ingin bercerai, ekonomi, peselingkuhan atau yang paling sepele adalah orang tua terlalu ikut campur dalam hubungan kedua belah pihak sehingga salah satu pasangan merasa tidak dihargai" (Wawancara, 5 Januari 2018).

Namun tidak hanya faktor internal saja yang menjadi permasalahan hingga kasus penggungatan perceraian berlanjut.Faktor eksternal juga membawa pengaruh besar pada hubungan rumah tangga. Contohnya, seperti yangdinyatakan oleh Muzam (30) penggugat atau suami dari Lia tergugat di Mahkamah Syari'iyah Kota Lhokseumawe :

"Iyah, penyebab perceraian saya, karena ibu istri terlalu ikut campur dalam hubungan kami, seperti saya tidak punya hak atas istri saya" (Wawancara, 5 Januari 2018).

Pernyataan senada juga disampaikan,Lia (28) penggugat perceraian atau istri Muzam (30) di Mahkamah Syar'iyah Lhokseumawe:

"Iyah, ibu saya masih sangat posesif dengan saya, tidak mengijinkan saya tinggal diluar selain dirumahnya" (Wawancara, 5 Januari 2018).

Pernyataan tersebut, menjelaskan berbagai macam problematika penyebab perceraian, yang dimana jika tidak dapat 
toleransi lagi kedua belah pihak lebih mementingkan egoisme masing-masing.

Berikut pernyataan,DRS. Nailul Syukri SH,MH (51)Hakim Mahkamah Syar'iyah Lhokseumawe :

"Banyak memang permasalahan yang ada pada kasus perceraian, namun saat mediasi ada beberapa permasalahan yang masih bisa ditoleransi, jika saat mediasi tidak menghasilkan kesepakatan rujuk, penggugat dan tergugat dapat bercerai seperti lebih mementingkan egoisme masing-masing "(Wawancara, 5 Januari 2018)

Hal senada di sampaikan oleh, Robinhot Kaloko, SH.MH (57)Hakim Mahkamah Syar'iyah Lhokseumawe :

"Iyah, kita lihat juga masalah yang menimpa pasangan, jika memang sudah merugikan satu pihak juga kami tidak bisa memberikan strategi karena sayang yang dirugikan selebihnya semua tergantung kepada pihakyang bersangkutan" (Wawancara, 5 Januari 2018).

Pernyataan tersebut menjelaskan bahwa, sebesar apapun upaya mediator mencoba melakukan mediasi terhadap pasangan suami istri, namun pilihan tetap kembali pada individu masingmasing. Walau masalah yang terjadi masih dapat ditoleransi, namun perceraian kemungkinan terjadi.Sebab, penggugat maupun tergugat tidak juga ingin berdamai karena lebih mementingkan egoisme masing-masing, hingga hasil akhir yang ditempuh adalah bercerai

Berdasarkan hasil penelitian, maka dari itu pada awal pertemuan mediasi, hakimyang berperan sebagai mediator memperkenalkan diri kepada pihak yang bersangkutan, lalu memberi tahu tata tertib yang dilakukan saat berlangsungnya mediasi dan mendata informasi mengenai para pihak baik penggugat maupun tergugat.Ini kiranya menjadi strategi awal hakim dalam mediasi.Hakim menjalankan tahapan kedua untuk melanjutkan strategi demi mediasi agar tidak terjadi perceraian.

Tahapan kedua adalah pertukaran penjajakan afektif (exploratory affective exchange stage). Pada tahap ini, yang 
mengikuti proses mediasi mulai memilikiperluasan dari area masalah kepada wilayah publik. Artinya hakim mulai mendapatkan ungkapan yang bersifat lebih personal.Akhirnya, komunikasi juga berlangsung sedikit lebih spontan karena individu merasa lebih santai dengan lawan bicaranya.Namun, bukan tidak mungkin mediasitetap berlanjut dengan lancar setelah tahapan ini.Hakim juga harus menjalankan strategi dengan sistem kaukus.

Strategi kaukus sendiri adalah situasi di mana saat melakukan mediasi, hakim sebagai mediator harus berhadapan dengan penggugat dan tergugat agar dapat berbicara langsung dengan pihak yang bersangkutan dengan cara terpisah. Kaukus ini berfungsi, dimana seorang mediator berbicara langsung kepada salah satu pihak, kemudian berbicara lagi dengan pihak lain, dan dapat menyimpulkan berbagai hal positif apa yang diinginkan salah satu pihak atau pihak lainnya.

Hakim mengajakwali untuk ikut andil menasehati atau dengan menasehati secara psikologi dengan menggunakan anak serta menjelaskan jika korban perceraian yang paling dirugikan adalah anak dan strategi lain dari sebuah mediasi adalah, mediator juga dapat mempertemukan kedua belah pihak, kemudian mediator meminta kedua belah pihak untuk membuat draf kesepakatan atau hal-hal yang di inginkan hingga, apabila kesepatakan itu disepakati biasa disebut dengan akta perdamaian, serta akta perdamaian ini, akan di serahkan kepada oleh majelis hakim.

Berdasarkan hasil penelitian, tahapan kedua telah dikantongi hakim untuk melanjutkan ke tahap berikutnya.Karena sebenarnya dua tahap saja tidak cukup untuk menguak akar masalah yang terjadi dalam kasus kisruh rumah tangga.Oleh sebab itu, kita akan beranjak pada tahap ketiga.

Tahap selanjutnya adalah pertukaran afektif (Exploratory Exchange Stage). Pada tahap ini, strategi akan lebih mudah dijalankan sebab, komunikan telah memiliki kenyamanan dengan komunikator.Oleh karena itu, saat berinteraksi pada tahap ini pun akan lebih santai.Komunikasi interpersonal yang berjalan pun spontan dan individu membuat keputusan dengan cepat.Tahap ini ditandai dengan munculnya hubungan persahabatan yang dekat. Pada tahap ini juga muncul perasaan kritis dan evaluatif pada level yang lebih dalam.

Namun demikian, tahapan ini juga ditandai dengan adanya perilaku saling kritik, perbedaan pendapat dan bahkan permusuhan 
antar individu, tetapi semua itu, belum berpotensi mampu mengancam kelangsungan hubungan yang sudah terbina.Pada tahap ini, tidak ada hambatan untuk saling mendekatkan diri, namun demikian, banyak orang masih berupaya untuk melindungi diri mereka agar tidak merasa terlalu lemah atau rapuh dengan tidak mengungkapkan informasi diri yang terlalu sensitif.

Berdasarkan hasil penelitian, hakim atau mediator telah memiliki komunikasi yang baik dalam mediasi. Namun, informasi sensitif yang diterima oleh mediator dalammediasidengan berbagai aspek atau alasan perceraian seperti; tidak memiliki keturunan, pasangan sakit berat hingga tidak dapat sembuh kembali, cacat fisik atau cacat mental, tidak ada kerukunan dirumah tangga atau terjadi keributan secara terus menerus yang tidak dapat hal yang bisa dijadikan alasan mereka bersama-sama lagi, adanya orang ketiga, dan adanya ikut campur orang tua dalam rumah tangga; terpaksa membuat hakim berusaha keras menyatukan hubungan yang nyaris retak tersebut.

Berdasarkan teori, hal tersebut dapat terungkap karena tahap akhir sudah dimiliki hakim.Tahap akhir dari teori penetrasi sosial ini adalah tahap pertukaran stabil (stable exchange stage).Dalam tahap ini, hal yangberhubungan dengan pemikiran, perasaan dan perilaku akan diungkapkan secara terbuka. Tidak banyak hubungan antar-individu yang mencapai tahapan ini.

Individu menunjukkan perilaku yang sangat intim sekaligus sinkron yang berarti perilaku masing-masing individu sering kali berulang, dan perilaku yang berulang itu dapat diantisipasi atau diperkirakan oleh pihak lain secara cukup akurat. Hal ini disebabkan masing-masing pihak telah cukup berpengalaman dalam melakukan klarifikasi satu sama lain terhadap berbagai keraguan pada makna yang disampaikan.Pada tahap ini individu telah membangun sistem komunikasi personal mereka yangakan menghasilkan komunikasi yang efisien.

Komunikasi dari berbagai tahap yang dilalui telah efektif.Hal ini dilihat dari walau banyaknya jenis masalah perceraian yang ada, seorangmediator dalam mediasi tetap bersikap netral dalam menghadapi sebuah mediasi, hingga tidak adanya berat sebelah pihak, yang dapat merugikan salah satu pihak. Oleh karena itu, hakim mediator harus tertuju dan tetap fokus pada pedoman sebagai hakim dan kode etik yang hal tersebut juga berlaku pada seorang mediator terutama seorang mediator hakim.

104

Jurnal Jurnalisme Volume 7 No. 1 Edisi April 2018 
Hasil akhir pembahasan membuktikan, seberapa besar strategi yang dilakukan oleh hakim sebagai mediator, dengan berbagai sulitnya permasalahan yang dihadapi oleh seorang mediator dalam menangani khasus perceraian, dari pihak mediator menyebutkan perbandingan, dari 100 hanya ada 1 orang yang mungkin akan berhasil pada titik mediasi dengan kata lain sangat sedikit berhasil sebuah mediasi perceraian.

Oleh karena itu, mediator telah melakukan tugasnya pada proses mediasi sesuai dengan fungsinya di Mahkamah Syar'iyah kota Lhoskeumawe ditambah berbagai strategi salah satunya dengan menggunakan komunikasi interpersonal yang baik,mengajak orang tua atau wali ikut menasehati dan berbicara secara psikologi dengan membawa nama anak sebagai korban utama perceraian baik kepada masing-masing pihak sampai menghadapkan pihak tersebut.

Namun hal tersebut tidak akan berhasil jika kedua belah pihak masih mengutamakan egoisme dari kedua belah pihak hingga keberhasilan mediasi, tetap gagal meskipun dengan berbagai ilmu dan usaha lain yang dimiliki oleh seorang mediator dalam memimpin sebuah mediasi.

Jadi, sebenarnya tahapan dari teori penetrasi sosial telah dikantongi oleh hakim dan orang yang terlibat kasus perceraian. Akan tetapi, sifat dari masing-masing yang terlibat tersebut, membuat hakim atau para pendukung keberhasilan mediasi lainnya tidak dapat memberikan hasil yang lebih baik untuk kelangsungan hubungan rumah tangga mereka. Sebab dalam proses hingga hasil mediasi, hakim maupun pihak lain tidak dapat mengambil keputusan. Hanya suami istri yang terlibat sajalah yang berwenang untuk memegang keputusan hubungan mereka.

\section{Penutup}

Strategi komunikasi interpersonal hakim pada mediator khususnya pada perkara perceraian di Mahkamah Syar'iyah Kota dengan mengoptimalkan proses mediasi antara penuntut yang dituntut. Seorang hakim juga dapat tugas sebagai mediator dengan ketentuan yang telah disetujui atau diutus oleh majelis pengadilan, yang mana harus mempunyai ciri-ciri atau karakteristik sebagai mediator salah satunya dapat berkomunikasi dengan baik agar dapat menyampaikan pesan yang baik terhadap pihak penggugat atau tergugat serta mengetahui ilmu mengenai mediasi serta 
berbagai aturan yang ada saat berlangsungnya mediasi dengan amat baik.

Strategi seorang mediator dalam menjalankan mediasi kepada proses perceraian adalah dengan berbicara langsung antara masingmasing pihak secara terpisah atau biasa disebut dengan Kaukus dalam mediasi, hal lainnya meminta wali atau orang tua ikut menasehati saat mediasi dan strategi lainnya berbicara secara psikologi mengenai anak, sebagai salah satu strategi jika bercerai anak adalah korban utama dari perceraian, serta strategi lanjutan adalah mempertemukan antara kedua belah pihak hingga dapat membuat draf kesepakan agar hasil akhir dari persidangan perceraian tidak merugikan kedua belah pihak. Seorang mediator juga harus mempunyai sikap netral dimana, harus berpedoman pada kode etik yang telah berlaku pada hakim dan juga berlaku pada seorang mediator.

Hasil analisis menyatakan, jika seorang mediator telah melakukan komunikasi interpersonal sebagai strategi dalam sebuah mediasi dengan baik dan sesuai dengan perannya, namun dengan banyaknya khasus penyebab adanya perceraian, seperti, tidak dapat memiliki keturunan, adanya kekerasan dalam rumah tangga, keributan yang berkepanjangan, adanya orang ketiga, ikut campur orang tua dalam rumah tangga serta hal lainnya. sebaik apapun usaha seorang mediator dalam menangani khasus mediasi atau dengan komunikasi interpersonal yang baik, keputusan semua ada ditangan kedua belah pihak hingga ketika kedua belah pihak masih dapat mempertahankan pernikahan, mediator sudah memerankan perannya dengan baik, maka semua berasal dari egoisme masingmasing kedua belah pihak, salah satunya jika dibandingkan dengan jumlah keberhasilan mediasi 100 hanya 1 yang berhasil damai untuk kembali sebagai suami istri.

\section{Daftar Pustaka}

Abbas, Syahrizal. (2009). Mediasi (Dalam Perspektif Hukum Syar'iyah, Hukum Adat, Dan Hukum Nasional). Jakarta: Kencana Prenada Media Group.

(2011). Mediasi dalam Hukum Syar'iyah, Hukum adat, dan Hukum Nasional. Jakarta : Kencana Prenada Media Group. 
Abdul Manan.(2005).Aspek-aspek Pengubah Hukum. Jakarta : Kencana Prenada Media Group.

Aw, Surantto. (2010). Komunikasi Interpersonal. Yogyakarta: Graha Ilmu.

DeVito, Joseph A. (2011). Komunikasi Antarmanusia. Tangerang Selatan: Kharisma Publishing Group.

Effendy, Onong Uchjana. (2003). Ilmu, Teori, dan Filsafat komunikasi. Bandung: PT. Citra Aditya Bakti

Hasan, M. Iqbal. (2002.). Pokok-pokok Materi Metodologi Penelitian dan Aplikasinya. Bogor : Ghalia Indonesia.

Lexy J, Moleong. (2006). Metodologi Penelitian Kualitatif. Bandung: PT. Remaja Rosdakarya.

Lexy J. Moleong,(2005). Metode Penelitian Kualitatif, Bandung, PT. Remaja Rosda Karya.

Liliweri, Alo. (1997). Komunkasi Antar Pribadi. Bandung : PT. Citra Aditya Bakti,.

Littlejohn, Stephen W. (2009). Teori Komunikasi: Theories of Human Communication. Jakarta: Penerbit Salemba Humanika.

Margono, Suyud. (2000). Alternatif Dispute Resolution dan Arbitrase. Jakarta: Ghalia Indonesia.

Morissan, Andy Corry W, Farid Hamid. (2010). Teori Komunikasi Massa, Media, Budaya, dan Masyarakat. Bogor: Ghalia Indonesia

Mulyana, Deddy. (2008). Metodologi Penelitian Komunikasi. Bandung : Remaja Posda Karya. 
Mulyadi, Lilik. (2010) Kompilasi Hukum Pidana Dalam Perspektif Teoritis dan Praktik Peradilan. Bandung: Penerbit Mandar Maju.

Pawito. (2007). Penelitian Komunikasi Kualitatif . PT LKiS Pelangi Aksara

West, Richard dan Lynn H. Turner. (2011). Pengantar Teori Komunikasi, Edisi 3 Analisis dan Aplikasi Buku 1 terjemahan. Jakarta: Penertbit Salemba Humanika 